\title{
Collective Security - The Role of International Organizations - Implications in International Security Order
}

\author{
Dr Stefan Aleksovski \\ Full Professor at the Faculty of Law \\ stevan.aleksoski@ugd.edu.mk \\ Dr Oliver Bakreski \\ Associate Professor at the Faculty of Philosophy - Institute of Security, Defence and Peace in Skopje \\ oliver@fzf.ukim.edu.mk \\ M.A. Biljana Avramovska \\ Ministry of defence of the Republic of Macedonia \\ a_biljana@yahoo.com
}

Doi:10.5901/mjss.2014.v5n27p274

\begin{abstract}
The principle of Collective Security provides rationality for a range of international organisations - such as the UN, NATO, EU, and OSCE - which all attempt to uphold international peace and stability. What is the utility of collective security? How does it contribute to international peace and security? This paper reflects on these fundamental questions through an analysis of collective security principles at work in Euro-Atlantic space. It first raises and answers the question: what is Collective Security. Second, it examines the operationalisation of collective security, defence and cooperative security principles in historical and contemporary spheres. It focuses on the collective security principle at work in the League of Nations, UN, NATO, EU and OSCE. It asks of these examples - what are the perceived strengths and weaknesses of collective security when it is applied? Third, it concludes by arguing whether the existing collective security organizations in Europe and Euro-Atlantic region can serve as a universal mechanism for collective security or collective defence, cooperation and conflict prevention and analyse, the organising principles, logic and architecture of European security, the necessity for redefinition of the existing European security order.
\end{abstract}

Keywords: collective security, international organizations, UN, NATO, EU, OSCE

\section{What is Collective Security?}

The centuries of experiences so far in the international efforts for finding global peace show that the traditional concepts of security do not provide adequate solutions for the current challenges of inter-state conflict and regional instability. In the research of this very significant and current segment of collective security, as opposed to the threats to world peace and stability, one can find two directions in international relations which are treated as: realism and liberalism, both demonstrating an era when war was considered as a legitimate instrument in politics. In the first years of the $20^{\text {th }}$ century we witnessed a new approach in politics, which in global frame works with the international security relation.

When we speak about this subject we undoubtedly think of the efforts of the international community for finding new ways and methods that lead to building mutual trust among countries, solving the so-called "security dilemma" through generally acceptable models of cooperation. Most of them see the framework as helping to achieve their own security and strengthening their security by being members of the collective systems for security, which certainly does not exclude their active participation in other international organisation. The subject of security is very current and complex. Security matters. It is impossible to make sense of world politics without reference to it.

The terms collective security and collective defence are inventions of the past century. The two concepts are a long-term formal commitment among groups of countries in order to protect the security interests of the individual members within their joint spheres of interest. The concept of "collective security" is deemed to apply interest in security in a broad manner, to "avoid grouping powers into opposing camps, and refusing to draw dividing lines that would leave 
out powers". ${ }^{1}$ The term "collective security" has been cited as a principle of the United Nations, and the League of Nations before that. Immanuel Kant presented this idea in his book towards the end of the 18 century "Perpetual Peace", in which he states that the "the law of nations will be based on one federation of free states". ${ }^{2}$ By employing a system of collective security any member state is dissuaded from acting in a manner likely to threaten peace, thereby avoiding conflict.

Collective security penetrates from the inside in order to create security within sovereign states. From this we can confirm that the level of collective security depends in large measure on liberal democracy. On the other hand, the unity in the field of collective security is followed by strong economic cooperation within the region, joint respect of the rule of law, supported by the fact that all of the Western European countries are liberal democracies, which is an imperative today for all countries in transition.

In a system of collective security, the enemy is a threat to regional or international peace and security. If the system of collective security is international in its reach, a threat can originate in any region, anywhere on the globe. Any nation within the regional or international system that commits aggression, imperils the peace, or grossly exceeds the bounds of civilised behaviour violates the norms of that collective security system and is subject to enforcement action. No nation is excluded from the responsibility of maintaining peace and security regardless of where, within its collective security system, the threat originates. Collective security can be triggered in another way. A threatened nation, exercising its inherent right of collective self-defence, can call on others to help. ${ }^{3}$

Collective defence is an arrangement, usually formalised by a treaty and organisation, among participant states that commit support in defence of a member state if it is attacked by another state outside the organization. ${ }^{4}$ NATO is the best known collective defence organisation - the famous Article 5 calls on member states to assist another member if attacked. This article was invoked after the September 11 attacks on the United States, after which NATO members provided assistance to the US War on Terror in Afghanistan. Collective defence has its roots in multiparty alliances and entails benefits as well as risks. On the other hand, by combining and pooling resources, it can reduce any single state's cost of fully providing security.

"Cooperative security" can be defined as sustainable efforts to reduce the risk of war which are not directed towards a specific country or coalition of countries and can be said to have appeared in the recent period, when the countries are developing the spirit of a common future. ${ }^{56}$ By accepting the new approach to develop cooperative security the countries begin to understand that the unilateral efforts to increase their security may be doomed to failure, since the activities of one country cause the same reactions by another country, which consequently decreases the security of both.

\section{Five Case Studies: Strengths and Weaknesses - Examples of Collective Security Principles at Work}

We can now turn to examine the operationationalisation of collective security, defence and cooperative security principles in historical and contemporary spheres. Let us look in turn at the strengths and weaknesses of the principle in the League of Nations, UN, NATO, EU and OSCE, to see if there are lessons identified and learned.

\footnotetext{
1 Yost, David, S, NATO Transformed: The alliance's New Roles in International Security (London: Leicester University Press, 1977), 149. http://www.answers.com/topic/collective-security-2

2 Immanuel Kant, Perpetual Peace (Cambridge: Cambridge University Press, 1991), pp. 93-130.

3 U.S. Permanent Representative to the United Nations Madeleine K. Albright speech - Transcript, Building a collective security system (US Department of State Dispatch, May 10, 1993), http://findarticles.com/p/articles/mi_m1584/is_n19_v4/ai_13180855/

${ }^{4}$ Claude Jr. Inis L, "Collective Security as an Approach to Peace", in Classic Readings and Contemporary Debates in International Relations, ed. Donald M, Donald M. Goldstein, Phil Williams, \& Jay M. Shafritz, (Belmont, 2006), pp. 289-302.

Munich Security Conference, Vladimir Putin's speech on the Munich Security Conference (February 10, 2007), http://www.securityconference.de/Putin-s-speech.381.0.html? \&L=1

OSCE, The statement by Sergey Lavrov, at the opening of the ASRC (Vienna, June 23, 2009), http://www.osce.org/ documents/cio/2009/06/38332_en.pdf

Mark Entin and Andrei Zagorski. "Can the European Security Dialogue Return Russia the Sense of Ownership of the OSCE?" in Russia, OSCE and European Security, ed. Fraser Cameron, Dov Lynch, Mark Entin, Andrei Zagorski, Vladimir D Shkolnikov, Pál Dunay, Andrei Fedarau, Vlad Lupan, Olena Prystayko, Olexandr Sushko, (Brussels: EU-Russia Centre, 2009), 18.

${ }_{6}^{6}$ Zoran Nacev i Radko Nacevski. Bezbednost i nacionalna odbrana (Kumanovo: Makedonska Riznica, 2001),p. 56. 


\subsection{The League of Nations:}

The first modern organisation for collective security was the League of Nations created after the First World War. The League of Nations grew out of World War I (1914-1918). However, the idea of the establishment of a body in which the nations of the world could settle their disagreements has been put forth periodically since antiquity. The League, created at the 1919 Paris Peace Conference, was the first organisation of sovereign states designed to be universal and devoted to the settlement of disputes and the prevention of war. ${ }^{7}$

In order to create the legal framework for executing this most complex task of the League, the members included a special provision in the Pact they signed. Article 10 states that "The Members of the League undertake to respect and preserve as against external aggression the territorial integrity and existing political independence of all Members of the League. In the case of any such aggression or in case of any threat or danger of such aggression the Council shall advise upon the means by which this obligation shall be fulfilled". ${ }^{8}$ The most controversial and debated provision seemed to demand of member states an obligation to "preserve as against external aggression the territorial integrity and existing political independence of all members of the League". ${ }^{9}$ But, in fact, the League, through its council (upper chamber), could only request them to act, not force them to do so. Some of the issues that were to plague collective security thus arose early: Is it possible to get binding commitments from states to suppress any future forcible alteration of the status quo? Is this even desirable, since the status quo may not be just or reasonable, at least not to everybody? ${ }^{10}$

How might we account for this failure? Theoretically, the League was allowed to use military force, but it did not have an army of its own - so if a country ignored it, in the end, there was nothing the League could do. Although the French (for obvious reasons) asked for the creation of an international army under control of the League of Nations, this idea received no serious support. Frightened by the spectre of American soldiers being summoned to fight on foreign soil at the behest of an alien organization, the Senate refused to ratify the Treaty of Versailles. Thus, the United States did not become a member of the league, nor was the new, outcast Russian socialist state a member.

The failure of the League of Nations discovered the need for liberal democratic countries. The problems of the League appeared from its non-democratic members. It could include fascist Italy, but not also fascist Germany. As soon as Germany became fascist, it left the League, thus the League was not able to survive and act anymore. The League's failure to prevent the outbreak of World War II in 1939 did not destroy the belief in the need for a universal organisation. On the contrary, it bred a determination to learn from the mistakes of the past and to build a new body more adequately equipped to maintain international peace in the future.

The central idea of collective security is to institutionalise a permanent arrangement of the balance of power in which the entire international community agrees to oppose military aggression by any member. The logic of the scheme is that no state can stand up to all of the other members of the system together, and that aggression will therefore be permanently deterred (an assumption made difficult when there are nuclear powers in the system). ${ }^{11}$

The necessary conditions for collective security are very demanding. First, all states must accept the status quo sufficiently to renounce the use of force for any purpose other than defence of their own territory. Second, all states must agree on a clear definition of aggression so that paralysis can be avoided if cases arise. Third, all states, and especially the large powers, must be willing to commit their own armed forces and/or funds (or to create, pay for, and find means of controlling, an international armed force) to prevent aggression even if it is remote from, or opposed to, their immediate interests. Fourth, all states must actively prevent any breaches of sanctions that might assist the declared outlaw. ${ }^{12}$ Attempts by the League of Nations to implement collective security failed because of inability to meet these conditions.

Some argued that the idea of collective security was even an obstacle to a firm policy, because public opinion at times, as in the United Kingdom in the mid-1930s, tended to look upon collective security and the league as a substitute for national power. Evidently, some people thought that if only the problem of stopping the dictators could be turned over to Geneva, nothing need be done by the separate nations. This clearly was a dangerous illusion.

\footnotetext{
7 Encyclopedia of the Nations, Comparison with the League of Nations, http://www.nationsencyclopedia.com/United-Nations/ Comparison-with-the-League-of-Nations.html

${ }^{8}$ Yale Law School, The Avalon project, Documents, History and diplomacy, The Covenant of the League of Nations ( June 28, 1919), http://avalon.law.yale.edu/imt/parti.asp.

9 lbid.

10 Williams Bruce Stockton, State security and the League of Nations (Baltimore: The Johns Hopkins Press, 1927), p. 346.

11 Political Dictionary, The Concise Oxford Dictionary of Politics (Oxford University Press, 2003), http://www.answers.com/topics/ collective-security-2

${ }^{12}$ Collective security, Political Dictionary http://www.answers.com/topics/collective-security-2 


\subsection{The Role of the UN in the system of Collective Security}

The UN as the successor of the League of Nations is a collective security system but with certainty created to correct the larger drawbacks of its predecessor. The UN unlike the League has universal membership. Namely, the UN is a universal international organisation that forbids war as a means of the international policy of the states. The rule of peaceful solution of disputes and for collective actions in cases of jeopardy of international peace and security dominates. Collective security operations of the UN occurred twice.

The UN Charter clearly states in Article 51 "nothing in the present Charter shall impair the inherent right of individual or collective self-defence if an armed attack occurs against a Member of the United Nations, until the Security Council has taken measures necessary to maintain international peace and security. Measures taken by Members in the exercise of this right of self-defence shall be immediately reported to the Security Council and shall not in any way affect the authority and responsibility of the Security Council under the present Charter to take at any time such action as it deems necessary in order to maintain or restore international peace and security". ${ }^{13}$ Individual self-defence according to the Charter can be taken by a country which is target of an armed attack until the moment the Security Council intervenes with its mechanisms.

In the last decade of the $20^{\text {th }}$ century, we saw such changes that had great influence on international stability and meaning and according to this the organisation itself as a universal organisation obliged to safeguard the world peace and security. Having in mind the opposed values of the member countries, the UN more often than not is an ineffective organisation, as a collective security system. This is confirmed by the fact that agreements are rare when the interests of the permanent members of the Security Council are in conflict. The two collective security operations which were "successful" illustrate the need of common values and interests. The UN was mostly effective against North Korea in 1950 but only because the Soviet Union boycotted the sessions of the Council. At that time the permanent members were: the USA, the United Kingdom, France, the Republic of China and the Soviet Union.

The end of the Cold War allowed the opportunity for the second successful operation for collective security of the UN against the Iraqi invasion of Kuwait in 1990. At that time the Soviet Union, expressed its desire to join the Western community of nations and did not block the action against Iraq which was its former "client". The Persian Gulf crisis showed that for the first time since the creation of the UN the Security Council has started to function as it was envisaged by its founders. In the Persian Gulf crisis the Security Council, besides unanimously convicting the Iraqi aggression and requesting re-establishment of the integrity and sovereignty of Kuwait, also voted upon the mandatory application of economic and military sanctions on Iraq, which were fully implemented.

During the Kosovo crisis of 1999, there was no action against Serbia on behalf of the UN. Russia and China opposed the action, partly because involvement in the internal matters of Serbia would make room for intervention in similar domestic situations elsewhere, such as Chechnya in Russia and Tibet in China. ${ }^{14}$ Another example is the Iraq-Iran war, which the Security Council followed without powers, not having the possibilities even to establish the aggressor and the victim, which is one of its elementary obligations and duties. "Russia deems important is the throughout strengthening of the UN potential. The UN must rationally adapt itself to new world realities. It should also strengthen its influence and preserve its multinational nature and integrity of the UN Charter provisions. The reform of the UN Security Council is an essential component of its revitalisation. The time has come to speed up the search for a compromise formula of its expansion and increased efficiency of its work". 15

Most important of all is that the big collective security actions of the UN occurred only when the non-democratic members of the Security Council were either absent from the meetings or restrained from their liberal democrat copies.

The purpose of the UN is not to get us to heaven but to save us from hell. The UN has played an essential role in diffusing interstate and intrastate disputes, responding to humanitarian emergencies and elaborating norms for human rights. Over the past six decades, this world organization has demonstrated considerable creativity in navigating the constraints of power politics. However, as long as states fail to provide requisite resources and delegate authority, the

\footnotetext{
13 United Nations, Charter of the UN -Chapter VII: Action with respect of threats to the peace, breaches of the peace, and acts of aggression (26 June 1945). http://www.un.org/en/documents/charter/index.shtml

${ }_{14}^{14}$ Michael Mihalka, "Cooperative Security: From Theory to Practice", in Cooperative Security: New Horizons for International Order, ed. Richard Cohen and Michael Mihalka, (Garmisch-Partenkirchen: The Marshall Center Papers, no.3, 2000), p. 34.

15 President of Russia, Medvedev's Address to the 64th Session of the UN General Assembly (New York, September 23, 2009), http://eng.kremlin.ru/events/chronicle/2009/09/221867.shtml 
UN's capacity to fulfil its mandate will remain circumscribed. ${ }^{16}$

However, the contemporary tendencies and the modern orientation of the UN, no matter the weaknesses in the practical realisation as far as the functioning and the accomplished results regarding the peace actions, are the greatest achievements. So far, in the international organisation in creating such international political and legal order in which the safeguarding of peace and the development of international cooperation will be prior goals and a guarantee for general progress and security for all of its members.

"The creation of the UN has become one of the main achievements of the world community in the 20th century. The UN and its activities are a true symbol of the 20th century. There is no, and there cannot be, alternative to this organisation and its fruitful efforts. We have no right to forget that the UN possesses a unique international legitimacy. And we all must preserve and strengthen this shared wealth of the peoples of the world". ${ }^{17}$

\subsection{NATO - a practical example of collective defense}

For many years NATO has been a successful example for the organization of collective defence. Article 5 from the Washington Treaty from 1949, which is the founding document of NATO, put this role in the centre of the Alliance's functions. "The Parties agree that an armed attack against one or more of them in Europe or North America shall be considered an attack against them all and consequently they agree that, if such an armed attack occurs, each of them, in exercise of the right of individual or collective self-defence recognised by Article 51 of the Charter of the UN, will assist the Party or Parties so attacked by taking forthwith, individually and in concert with the other Parties, such action as it deems necessary, including the use of armed force, to restore and maintain the security of the North Atlantic area. Any such armed attack and all measures taken as a result thereof shall immediately be reported to the Security Council. Such measures shall be terminated when the Security Council has taken the measures necessary to restore and maintain international peace and security". ${ }^{18}$

The Greek - Turkish differences in many issues would have surely resulted in at least one war between these countries if they had not been members of NATO. The informal, but intensive, bilateral and multilateral consultations within NATO diminished the Greece-Turkey conflict in many cases (most spectacularly in the summer of 1974). Such war would have been a great impact on NATO solidarity and its long-term future.

After the tectonic movements in Central and Eastern European as well as in the Balkans, especially after the dissolution of the Warsaw Pact and the incapacity of the EU to affect the "open fires" in the former Yugoslavia and the former Soviet Union, the debates on NATO and its destiny and role intensified as well as its role in the security system. Those debates moved in a wide range starting from the grade that NATO managed to win the Warsaw Treaty and thus shot "no bullets", which brings one to the conclusion that NATO should stay in Europe, to the grade that that robust miracle of the Cold War should be abolished and disbanded.

Many analysts who claimed that the EU will "nationalise again" its security policy after the end of the Cold War, believed that NATO will disappear after its "main threat" the Warsaw Pact, has dissolved. These analysts were trapped in the realistic tradition and were not compliant with the common transatlantic identity of the Alliance members.

According to Solana, NATO is redefining itself on the basis of the security definition, which is essentially different from the one used during the Cold War. "In the expansion of the security concept, in taking over new roles and missions, in the adaptation at large scale, NATO today is not about the defence from attack at great scale. The central position belongs to the creation of security within the societies, creating conditions for stability, in which the respect of the human rights, consolidation of the democratic reforms and economic trade patterns and investments will flourish... in brief; it is a new cooperative security order for the Euro-Atlantic order". ${ }^{19}$

How to deal with Russia? Before the Senate Armed Services Committee on April 23, 1997, Sen. Kempthorne asked, "if NATO is not-anti Russian, then what is it? Who is the alliance defending against?". Secretary of State Albright responded "The threat is basically....the instability within the region which has in fact created two world wars. But there is

\footnotetext{
16 Thomas G. Weiss and Danielle Zach Kalbacher, "The United Nations", in Security studies, ed. Paul D.Williams, (London and New York: Routledge, 2008), p. 342.

17 President of Russia, Medvedev's Address to the 64th Session of the UN General Assembly New York (September 23, 2009), http://eng.kremlin.ru/events/chronicle/2009/09/221867.shtm

18 NATO, The North Atlantic Treaty (Washington, 4 April 1949). http://www.nato.int/cps/en/natolive/official_texts_17120.htm

${ }^{19}$ NATO, Secretary General of NATO, Javier Solana, "The Role of NATO in Building Cooperative Security in Europe and Wider", speech at the Symposium for International Economy (Tokyo, Japan, 1997),

http://www.nato.int/cps/en/SID-912325B3F0EB4719/natolive/opinions_25561.htm?selectedLocale=en
} 
also the possibility of an outside threat. There is a possibility of threats from various parts outside the region, to the south, that we have to guard against. And, on the off-chance that in fact Russia does not turn out the way we are hoping it will and its current leadership wants, NATO is there". 20

The ultimate goal is to steer relations to calmer seas and to prevent rhetoric of daily politics from undermining cooperation. This requires a dual strategy: NATO should take Russia's concerns into account, but at the same time be firm on Russia's antagonistic and intimidating behaviour - be it against NATO itself or against its partners.

"We have real differences with Russia on several issues. And we intend to use the NATO-Russia Council as a forum for frank discussions about areas where we disagree. We will use it to press Russia to live up to its commitments on Georgia and to reiterate our commitment to the territorial integrity and sovereignty of all states. We will use it to challenge the assertion put forward in Russia's new military doctrine that NATO's enlargement and its global actions constitute a military danger to Russia. We will also use the Council to advocate on behalf of human rights and individual liberty - these are principles and values that Russia committed to uphold when it accepted the NATO-Russia Founding Act". ${ }^{21}$

What is required from NATO is a realistic assessment of the present situation. Given the developments, one can hardly expect the political leadership in Moscow to act meekly on the international stage. "Consequently, NATO must attempt to distinguish between rhetoric and reality, between Russian security interests and calculating political arguments. The real question facing NATO is what concrete potential for action lies behind Moscow's posturing". ${ }^{22}$

\subsection{The EU and its contribution to collective security}

The integration of Western Europe after World War II focused on the creation of security communities, especially in the development of the European Community; the current European Union. Thus, Karl Deutsch underlines that, in difference to the inter-war period, the western European countries do not plan wars against each other, but they underline the creation of a security community which is a reality today. The creators of the European Community have made conscious efforts to build a security community in Europe by strengthening the collective identity.

One of the founders of the European Community Jean Monnet wrote in 1944: "There will be no peace in Europe if the states are being created again on the basis of national sovereignty, with everything it brings, through the prestigious politics and economic protectionism. If the countries once again protect one from another, they will need to once again build big armies ... Europe will be once again born under the shadow of fear". ${ }^{23}$ As Robert Cooper put it, the Treaty of Rome is "a conscious and successful attempt to go beyond the national state, while modern Europe was born with the peace of Westphalia". ${ }^{24}$

It is the intention that EU remains a liberal democratic security community. The applicants need to fulfil the three main criteria for membership: progress to liberal democracy, progress to creating market economy and progress towards rule of law, thus fulfilling the basic standards for membership into the "high European society".

"Repeated nationalisation" of the national policy of the EU member states did not occur, and the EU is slowly but surely moving towards the coordination of individual national security policies. Several of its members already take part in the Euro-corps, which slowly takes the responsibility for the overall mission in Kosovo, in which the EU has almost all of the characteristics of a mature security community with cooperative security as a norm. ${ }^{25}$

What the EU has achieved in ten years in the security field is undeniable. The EU project was very ambitious, the path was narrow, and the EU was constantly watched, whatever it did or did not do. As of 2003, the EU has started to project security outside its borders through peace missions, which further contribute to its transformation as a security actor (but these activities have not transformed it into a global actor). The EU is a civilian power that has taken steps on

20 U.S. Government Office, The Committee on Foreign Relations: Hearing on NATO enlargement, Senate Armed Services Committee (Washington, April 23, 1997). p. 6.

${ }^{21}$ NATO, Hillary Rodham Clinton, Secretary of State, Remarks at the NATO Strategic Concept Seminar ( Washington, February 22, 2010), http://www.nato.int/cps/en/natolive/events_61583.htm.

22 Karl-Heinz Kamp, "After the summit: Long -term Consequences for NATO", in Research Paper Series, ed. NATO defense College No.37, (Rome: NATO Defense College, May, 2008)

${ }^{23}$ Ole Waever, "Insecurity, Security and Asecurity in the West European Non-War Community", in Security Communities, ed. Emanuel Adler and Michael Barnett, (Cambridge: Cambridge University Press 1998). 69.

${ }^{24}$ Robert Cooper, The breaking of nations: Order and Chaos in the Twenty-First Century, (New York: Grove press, 2003).

${ }^{25}$ Michael Mihalka, "Cooperative Security: From Theory to Practice", in Cooperative Security: New Horizons for International Order, ed. Richard Cohen and Michael Mihalka, (Garmisch-Partenkirchen: The Marshall Center Papers, no.3, 2000), p. 50. 
the way to militarization, but does not yet qualify as a full-fledged military power. ${ }^{26}$

The starting point must be that no real security is possible in Europe without US engagement and without Russia finding its proper place in the overall European order. Since the end of the Cold War we in the West certainly made mistakes and missed opportunities. But Russians also have to ask what they have contributed to the prevailing mood of distrust, especially among their neighbours. Shared security requires a shared mindset. An agreement on principles and a willingness to abide by them in practice. George Kennan wrote in his Long Telegram, explaining why the Soviet Union was not supportive of the new global institutions, that "Soviet power is impervious to the logic of reason...[but] highly sensitive to the logic of force".

"Today, Russia is very different from the Soviet Union in the wake of World War II. So too is Europe. That is why we want to believe that it is the logic of reason that drives the Russian leadership. And that is why we want to explore President Medvedev's idea of a new European security architecture and the environment created by the US "reset" within the EU-Russia partnership".27

\subsection{OSCE - A Platform for Cooperative Security}

The OSCE is different from NATO and EU. It is well - known that the members of the OSCE do not form a security community and the de jure and de facto situation' values differ, besides the official adjoining to the principles of Helsinki Final Act. The OSCE scope, although it spreads from Vancouver to Vladivostok and is very diverse, gives little ground for joint identity.

Composed of three "dimensions", the OSCE agenda intertwines the politico-military aspects of security with "economic/environmental and human dimension" matters. The development of the politico-military dimension presently faces difficulties raised by Russian grievances about insufficient military-security dialogue within the OSCE, non-updating of the CSBMs regime and non-ratification of the Adapted Conventional Armed Forces in Europe Treaty. ${ }^{28}$

The desire of the OSCE to achieve cooperative security is clearer in the intentions for strengthening the politicalmilitary security. The directions such as the OSCE Charter for European Security or the Code of Conduct for politicalmilitary aspects underline that security needs to be achieved jointly, with no country having primacy. What the OSCE is doing is nothing else but moving towards cooperative security, as an organisation which is founded on consensus. The OSCE needs to be seen also as an organization which sets norms. At the OSCE Summit in Istanbul in November 1999 there was the adoption of the Platform for cooperative security within the Charter for European Security. The OSCE offers the platform as a cooperative framework to work in sub-regional context. According to this platform, we can see the OSCE more as a "market" than as a "factory" within the countries, and the international organisations can choose the manner of cooperation.

Besides these values, the larger numbers of experts consider that the OSCE does not fulfil all the criteria of a security community. In favour of this is the fact that some members of the OSCE have recently been at war with one another or intend such actions in the future. But the force of the OSCE lies in providing the possibility for cooperation with the countries according to their political will and by setting regional norms. For now, it is evident that it is no accident that those countries which mostly use OSCE capabilities come from the western part of the Euro-Atlantic region, and the European countries only continue to cooperate in the security issues, on the basis of existing membership in institutions, which operate in the OSCE area.

The OSCE has unfinished business in a number of areas and untapped reserves able to catalyse cooperation on new questions. Given the complexity of new challenges and threats, the Organization stands well-placed to assist participating States through its flexible instruments and on the basis of a comprehensive approach to security. The challenge now is to determine the priorities for the organisation and to concentrate energy and recourses in a targeted manner. For all its difficulties and pressures, the OSCE has a vital role to play as a forum for permanent political engagement between the 56 States. ${ }^{29}$

From the early 1990s, Russia sought to reform the OSCE in order to strengthen it as a hub for the other security organisations in the Euro-Atlantic area. In 1999, Russia criticised the perceived failure of the OSCE in Kosovo, and the

${ }^{26}$ Thierry Tardy, "The European Union, a regional security actor with global aspiration", in European Security in a Global context, (London and New York: Routledge, 2009), p. 33.

${ }^{27}$ Council of the EU, Speech by Javier Solana, EU High representative for CFSP, "Europe in the world" (Harvard University, 17 September 2009), http://www.consilium.europa.eu/uedocs/cms_data/docs/pressdata/EN/discours/110218.pdf

${ }^{28}$ Victor-Yues Ghebali, "Where is OSCE going", in European Security in a Global context, (London and New York: Routledge, 2009), p. 56.

${ }^{29}$ Perrin de Brichambaut, Marc, "The OSCE and The 21st Century", Helsinki Monitor, Vol.18 Issue 3 July 2007, pp. 180-191. 
role this played in setting the ground for the NATO air campaign. In the wake of the "colour revolutions" in the former Soviet Union, Russia led the charge to redress perceived imbalances in OSCE work and to strengthen the Organisation's legal basis. Russian criticism came to a head in February 2007, when President Vladimir Putin declared to the 43rd Conference on Security Policy in Munich, "What do we see happening today [with the OSCE]? We see this balance [between the political-military, the economic and the human dimensions] is clearly destroyed. People are trying to transform the OSCE into a vulgar instrument designed to promote the foreign policy interests of one or a group of countries". 30

At the same time, the continuous eastward enlargement of NATO, alongside that of the European Union, put an end to the illusion that the new European order could be built on the basis of the OSCE, which was increasingly perceived in Moscow as an institution which had been captured by the West and become instrumental in pursuing the "western" agenda of those participating states which were not yet members of either NATO or of the EU.

This conclusion may have inspired the Russian Foreign Minister, Sergey Lavrov, to note in June 2009 at the opening of the OSCE Annual Security Review Conference that, "we differ on the methods of obtaining European unity. It would have sufficed to consequently institutionalise the OSCE and to turn it into a full-fledged regional organisation under Chapter VIII of the UN Charter. This means that the OSCE would address the whole spectrum of problems in the EuroAtlantic area. First and foremost, based on legal obligations, it would provide for an open collective security system in the region. Unfortunately, our western partners embarked on a different way that foresaw not only the preservation but, also, the enlargement of NATO". 31

The Russian Federation has become critical of the OSCE as it stands today. Moscow has argued that it has lost its focus on political-military cooperation, concentrating too much on issues of democratisation and human rights. Certainly, Russia took a dim view of the role of the OSCE in the run-up to the "colour revolutions" in Georgia, Ukraine, and Kyrgyzstan. For Moscow, the OSCE has also lost its geographic balance, focusing almost entirely on the countries east of Vienna. In the process, the OSCE is seen to have become an instrument for Western states, used often at the expense of Russian interests. The Corfu Process has shown already the role that the OSCE can play as a reference-point and platform for pan-European dialogue - in ways that are useful both for Russia and pan-European security. As the CSCE before, the OSCE cannot be all things to all masters, but it still represents an innovative and flexible meeting point for all states and a security organisation able to tackle common challenges to the security of Europe as well as in Europe. As in the past, Russian vision will be vital for taking the OSCE forward and for making the most of the newly-launched dialogue on European security.

Observing an increasing marginalisation of the OSCE against the dual enlargement of "western" institutions in Europe, Moscow will be asking why it should pay the price implicit in the comprehensive OSCE agenda which links human rights, pluralistic democracy and the rule of law to security. At the same time, the OSCE has been unable to deliver on its promise to either preserve the status quo in Europe, or preserve Russia's interest when the status quo began to ebb. ${ }^{32}$

\section{Conclusion}

Security matters. The acceptance of the security, conceptualised in the manner described above, can become the basis for a quieter and harmonic future. Thus, developed with four basic security parts - individual security, collective security, collective defence and promotion of stability - the system of cooperative security asks from the democratic countries which are its members, for a will for closer mutual cooperation, such as interventions outside of their territories, which can affect their common peace and security. As security communities, NATO and the EU have developed dense networks of multilateral institutions which promote the denationalisation of security policy and serve the needs of entire regions. It is by no accident that NATO and the EU promote liberal democracy, and they do it because they partly believe that the security is greater with the cooperation of the countries which have adopted liberal democracy as a form of government.

Institutions matter. NATO is a model for the system of collective defence. The EU is in the process of enlargement on a wider and deeper area of the Euro-Atlantic cooperative security. Finally, this space needs to be expanded in order to

\footnotetext{
${ }^{30}$ Munich Security Conference, Vladimir Putin's speech on the Munich Security Conference ( February 10, 2007), http://www. securityconference.de/Putin-s-speech.381.0.html?\&L=1

${ }^{31}$ OSCE, The statement by Sergey Lavrov, at the opening of the ASRC (Vienna, June 23, 2009), http://www.osce.org/documents/ cio/2009/06/38332_en.pdf

${ }^{32}$ Mark Entin and Andrei Zagorski. "Can the European Security Dialogue Return Russia the Sense of Ownership of the OSCE?" in Russia, OSCE and European Security, ed. Fraser Cameron, Dov Lynch, Mark Entin, Andrei Zagorski, Vladimir D Shkolnikov, Pál Dunay, Andrei Fedarau, Vlad Lupan, Olena Prystayko, Olexandr Sushko, (Brussels: EU-Russia Centre, 2009), p. 18. 
include the other parts of the Eurasian and Atlantic region, including Russia.

At the end, the success of any system of international security depends on the strong and united leadership, the spirit of compromise as well as the decisiveness of its members to hold till the end. This is particularly true for a complex institution such as the system of cooperative security. If these elements are missing, the system may not succeed. It will be thus, not because it has mistakes, but because its performers will not have the courage and wisdom to overcome the unavoidable difficulties and misunderstandings. Still, if they are wise, the leaders can overcome these obstacles, and the real and practical manifestation of the collective security can bring new hope in this insecure world.

\section{References}

Yost, David, S, NATO Transformed: The alliance's New Roles in International Security (London: Leicester University Press, 1977$), 149$. http://www.answers.com/topic/collective-security-

Immanuel Kant, Perpetual Peace (Cambridge: Cambridge University Press, 1991), 93-130.

U.S. Permanent Representative to the United Nations Madeleine K. Albright speech - Transcript, Building a collective security system (US Department of State Dispatch, May 10, 1993), http://findarticles.com/p/articles/mi_m1584/is_n19_v4/ai_13180855/

Claude Jr. Inis L, "Collective Security as an Approach to Peace", in Classic Readings and Contemporary Debates in International Relations, ed. Donald M, Donald M. Goldstein, Phil Williams, \& Jay M. Shafritz, (Belmont, 2006), 289-302.

Zoran Nacev i Radko Nacevski. Bezbednost i nacionalna odbrana (Kumanovo: Makedonska Riznica, 2001),56.

Encyclopedia of the Nations, Comparison with the League of Nations,http://www. nationsencyclopedia.com/United-Nations/Comparisonwith-the-League-of-Nations.html

Yale Law School, The Avalon project, Documents, History and diplomacy, The Covenant of the League of Nations ( June 28, 1919), http://avalon.law.yale.edu/imt/parti.asp.

Williams Bruce Stockton, State security and the League of Nations (Baltimore: The Johns Hopkins Press, 1927$), 346$.

Political Dictionary, The Concise Oxford Dictionary of Politics (Oxford University Press, 2003), http://www.answers.com/topics/collectivesecurity-2

Collective security, Political Dictionary http://www.answers.com/topics/collective-security-2

United Nations, Charter of the UN -Chapter VII: Action with respect of threats to the peace, breaches of the peace, and acts of aggression (26 June 1945). http://www.un.org/en/documents/charter/index.shtml

Michael Mihalka, "Cooperative Security: From Theory to Practice", in Cooperative Security: New Horizons for International Order, ed. Richard Cohen and Michael Mihalka, (Garmisch-Partenkirchen: The Ma1President of Russia, Medvedev's Address to the 64th Session of the UN General Assembly (New York, September 23, 2009), http://eng.kremlin.ru/events/chronicle/2009/ 09/221867.shtml

Thomas G. Weiss and Danielle Zach Kalbacher, "The United Nations", in Security studies, ed. Paul D.Williams, (London and New York: Routledge, 2008), 342

President of Russia, Medvedev's Address to the 64th Session of the UN General Assembly New York (September 23, 2009), http://eng.kremlin.ru/events/chronicle/2009/09/221867.shtm rshall Center Papers, no.3, 2000), 34.

NATO, The North Atlantic Treaty (Washington, 4 April 1949) http://www.nato.int/cps/en/natolive/official_texts_17120.htm

NATO, Secretary General of NATO, Javier Solana, "The Role of NATO in Building Cooperative Security in Europe and Wider", speech at the Symposium for International Economy (Tokyo, Japan, 1997),http://www.nato.int/cps/en/SID912325B3F0EB4719/natolive/ opinions_25561.htm?selectedLocale=en

U.S. Government Office, The Committee on Foreign Relations: Hearing on NATO enlargement, Senate Armed Services Committee (Washington, April 23, 1997).6.

NATO, Hillary Rodham Clinton, Secretary of State, Remarks at the NATO Strategic Concept Seminar (Washington, February 22, 2010), http://www.nato.int/cps/en/natolive/events_61583.htm.

Karl-Heinz Kamp, "After the summit: Long -term Consequences for NATO", in Research Paper Series, ed. NATO defense College No.37, (Rome: NATO Defense College, May, 2008)

Ole Waever, "Insecurity, Security and Asecurity in the West European Non-War Community", in Security Communities, ed. Emanuel Adler and Michael Barnett, (Cambridge: Cambridge University Press 1998). 69.

Robert Cooper, The breaking of nations: Order and Chaos in the Twenty-First Century, (New York: Grove press, 2003).

Michael Mihalka, "Cooperative Security: From Theory to Practice", in Cooperative Security: New Horizons for International Order, ed. Richard Cohen and Michael Mihalka, (Garmisch-Partenkirchen: The Marshall Center Papers, no.3, 2000), 50.

Thierry Tardy, "The European Union, a regional security actor with global aspiration", in European Security in a Global context, (London and New York: Routledge, 2009), 33.

Council of the EU, Speech by Javier Solana, EU High representative for CFSP, "Europe in the world" (Harvard University, 17 September 2009), http://www.consilium.europa.eu/uedocs/cms_data/docs/pressdata/EN/discours/110218.pdf 